\title{
The Effect of Organizational Tradition, Control, and Self- Efficacy on the Success of Civil Servants of Education Staff at the Ujung Pandang State Polytechnic Office
}

\author{
Fatmawati \\ Student of Management Magister Program \\ Sekolah Tinggi Ilmu Ekonomi Amkop, Makassar, Indonesia \\ fhatma.wati04@gmail.com \\ Hasmin Tamsah, Dian Anggriani Utina \\ Sekolah Tinggi Ilmu Ekonomi Amkop, Makassar, Indonesia \\ hasmin@stieamkop.ac.id, diananggriani86@yahoo.com \\ Buyung Romadhoni \\ Universitas Muhammadiyah Makassar, Makassar, Indonesia \\ buyung@unismuh.ac.id \\ Yusriadi Yusriadi \\ Sekolah Tinggi Ilmu Administrasi Puangrimaggalatung, Makassar, Indonesia \\ yusriadi.yusriadi@uqconnect.edu.au \\ M Chairul Basrun Umanailo, Sjaid S Fais Assagaf \\ Universitas Iqra Buru, Indonesia \\ chairulbasrun@gmail.com, sjaidfaisuniqbu@gmail.com
}

\begin{abstract}
This study aims to: (1) Analyze the influence of organizational culture on the performance of Civil Servant Education Personnel at the Ujung Pandang State Polytechnic office; (2) Analyzing the impact of the power of Locus of Control on the Performance of Civil Servant Education Personnel at the Ujung Pandang State Polytechnic Office; (3) Analyze the effect of Self Efficacy on the Performance of Civil Servant Education Personnel at the Ujung Pandang State Polytechnic Office. Civil servants of education personnel at the Ujung Pandang State Polytechnic Office are the object of researchers using organizational culture, which is a system adopted by the organization, and locus of control and self-efficacy as a trait personality. This study combines the procedure adopted and individual character to measure employee performance. The method used in this research is a quantitative approach. Sampling in this study used probability sampling techniques with the Slovin formula so that the total sample was 114 people. The data were collected using a questionnaire and then analyzed using the Structural Equation Model (SEM) method using the Smart PLS application.
\end{abstract}

Keywords: Organizational Culture, Locus of Control, Self-Efficacy, Performance, Indonesia

\section{Introduction}

Civil servants, abbreviated as PNS, are government workers offering facilities to society. The Government Law of the Republic of Indonesia No 11 of 2017 on the administration of PNS specifies that the State Civil Apparatus, from now on abbreviated as ASN, is an occupation for civil servants and government workers arrangements employed for government agencies. Nowadays, the public sector is always characterized as unproductive, wasteful, often at a loss, low in ingenuity, and high in innovation. One of the public sector governance changes, namely Modern Public Management, is implementing market processes and vocabulary in the public sector to contact government 
Proceedings of the 11th Annual International Conference on Industrial Engineering and Operations Management Singapore, March 7-11, 2021

institutions, and the community is fair in processing transactions (Awaluddin et al., 2019; Gani et al., 2019; Sahabuddin et al., 2019; Sahid et al., 2020; Usman et al., 2020). Denhardt (2000), concerning the importance of industry in the public sector, is known to kill the value of public administration to facilitate modern principles. The new deal from this viewpoint is the restoration of the group's status, namely the 'customer' to the real position of 'citizen/citizen.' Restoring the function of government from the point of view of new public administration, namely as a public servant.

The effectiveness of an Organisation in achieving its goals is one directed towards the capability of its personnel (Mustafa et al., 2020; Rahawarin et al., 2020; Rijal et al., 2019). Human resources ability requires actions, selfconfidence, and self-confidence, making it easier for agencies to guide all human capital (HR) accurately, efficiently, and sustainably to achieve the Agency's objectives (A'yun et al., 2017). Organizational culture often influences employee efficiency.

Self-esteem and employee confidence affect performance, like Gunawan \& Sutanto's (2013) research on the effect of organizational culture and self-efficacy on employee performance. It indicates that the self-efficacy component has a significant negative impact on results. In contrast, Sibuea \& Rustono's (2015) research on the effects of organizational culture on performance has had a significant adverse impact on performance. Person confidence in managing their destiny often affects success, such that Amalini et al. (2016) reported that Internal Locus of Control has a substantial positive impact on employees' performance. This study confirms the findings of Wahyuni \& Rosmida's (2017) research, which indicates that employees with internal control locus are doing well for the company, so that their performance is vital.

Research performed by Wiriani et al. (2013) argued that success is affected by human personality traits, i.e., someone with an internal control locus appears to be receptive, thereby improving their performance relative to someone with an external control locus. Someone with an internal control locus has more incentive, like a rival. Educational workers at the Ujung Pandang State Polytechnic Office are less willing to cope with the drop in results, which the full annual report can see of ELAPKIN SKP PPK 2017 PNUP of 14,437.51. In contrast, the full annual report of ELAPKIN SKP PPK 2018 is 10,901.63. This situation is attributed to employees who are less involved. Employees want to be ordered, and employees want to operate.

\section{Literature Review}

\subsection{Relationships between corporate culture and efficiency}

Based on the paradigm mentioned above of reasoning, the corporate culture is a value, a tradition, a mentality, a behavioral principle that is believed and utilized as a reference while operating in an organization. It becomes the personality of an organization. There is a need for a standard connection in a company such that workers may be optimally motivated (Rinantanti et al., 2019). These legal references are articulated in the context of a corporate culture that systematically directs workers to improve their contribution to work.

Organizational culture often influences employee efficiency, where corporate culture is characterized as beliefs and behaviors that are believed and recognized by all company employees as an organizational identity that can be utilized as a foundation for the achievement of objectives. Pratiwi (2012) claims that corporate culture has a significant influence on employee efficiency. In contrast, Yusuf's (2016) study has a negative and negligible impact on employee performance, since innovative workers are more straightforward to see what is valid and not, more centered, freer and less culturally tied, more spontaneous, more regular, and more individual.

H1: It is believed that the corporate atmosphere has a positive and essential influence on civil servants' success in preparing PNUP employees.

\subsection{Locus of Control Connection to Success}

Locus of influence is a person's assumption that achievement or loss arises from internal and external causes, either from self-control or chance, opportunity, and destiny.

Oktavia (2017) The management locus has a significant impact on the output of editorial workers. The dominant control locus is in the internal control locus of the editorial staff of PT. Intermedia Press Semarang. Previous experiments have found that the internal regulation locus has little impact on employee efficiency, as employee 
Proceedings of the 11th Annual International Conference on Industrial Engineering and Operations Management Singapore, March 7-11, 2021

performance is more prevalently impacted by work stress. (Subroto, 2017). -Yes. This analysis suggests that there are no effects on the control locus's efficiency, but there is an influence of work stress on employee performance.

This person is identified to be more reliant on his perceptions. The Locus of Influence's real success is defined by the confidence in its abilities to execute critical roles and responsibilities.

H2: The Locus of Control is believed to have a substantive and essential influence on civil servants' efficiency in preparing PNUP employees.

\subsection{Relationship of self-efficacy to success}

Self-efficacy is a person's self-assessment or degree of trust regarding how well he can complete an absolute duty to produce performance.

Self-esteem and employee confidence often affect efficiency, such that Gunawan \& Sutanto's (2013) research on the effect of organizational culture and self-efficacy on employee efficiency. It reveals that variable self-efficacy (selfefficacy) has a substantial negative impact on performance. Simultaneously, Sibuea \& Rustono's (2015) research on the influence of organizational culture on p. Self-efficiency benchmarks is calculated based on knowledge-based insights expressed with others, based on one's skills, and the basis of psychological factors.

H3: It is believed that self-efficacy has a positive and significant influence on the success of civil servants in the UNP

\section{Method}

This analysis's design is survey research, where survey research is a quantitative method to analyze participant and community habits. A survey study typically uses the questionnaire as the primary data collection and uses a population survey. Scholars often use correlation Analysis to analyze the association between two factors. Correlation cannot ensure causality (the causal relationship), but causality does guarantee correlation. According to Creswell (2016), the quantitative analysis method is a way to evaluate a hypothesis by assessing the interaction between various variables. This attribute is calculated using analytical instruments such that results in the form of numbers can be analyzed using statistical procedures.

This research uses three exogenous variables or variables that impact, namely organizational culture (X1), control locus (X2), and self-efficacy (X3), and one endogenous variable or variable that is affected, namely efficiency (Y). This study was carried out at the Ujung Pandang State Polytechnic Office, particularly in the administration area. The population this research was Civil Servants of Education Workers at the Ujung Pandang State Polytechnic Office, a total of 158 individuals, using the Slovin formula with a standard error of 0.05 samples was as large as 114 . Margono (2003) indicates that a sampling methodology is a tool for evaluating a selection whose number refers to the number of models used as a database by defining the population's features and distribution to produce a representative sample. The sampling methodology used in this analysis is chance sampling, a technique that offers fair chances for each member of the community to be chosen as part of the survey.

The questionnaire data outcomes were translated into numbers that were then processed using the Structural Equation Model (SEM). SEM is also known as Covariance Structure Analysis or Causal Simulation. Using Smart PLS 2 dynamic equations in SEM is simpler to solve than using other applications. Using Smart PLS 2 allows it to measure the interaction between variables, including between latent variables and markers or manifests. There are two types of variables dependent on the causal business, namely exogenous variables and endogenous variables. Sarwono (2012) PLS-SEM tests the outer model, the relationship between the manifest or indicator variable and the latent variable, how does each variable represent (reflect) the hand, and how does the latent variable shape the variable (formative) portion. In the meanwhile, the inner construction is a structural model that binds the latent variables.

\section{Results and Discussion}

This study aims to analyze the influence of organizational culture variables, locus of control, and self-efficacy on civil servants' performance for education personnel at the Ujung Pandang State Polytechnic office.

\subsection{Outer Model (Validity Test and Reliability Test)}

This research uses Smart PLS Version 2 software to include the validity and reliability tests in the outer model. The validity test was conducted to test the validity or suitability of the questionnaire used by researchers to obtain 
Proceedings of the 11th Annual International Conference on Industrial Engineering and Operations Management Singapore, March 7-11, 2021

respondent data. The truth can be seen from the average value of the variance extracted (AVE) and the value of communality $>0.5$.

\section{1) Validity Test}

The indicator is valid if it has a loading factor of $>0.5$ to the intended construct. There are two types of validity in PLS-SEM, namely convergent validity, and discriminant validity. Researchers use both validity tests, where the convergent validity test means that a set of indicators represents one latent variable, the value from the outer loading table is expected to be $>0.5$. In contrast, discriminant validity is used to determine the construct by comparing the loading value. In the intended construct, the loading value is more generous than other constructs. This value can be seen from the cross-loading table.

Table 1. Convergent Validity Test Outer Loading Results Table

\begin{tabular}{|l|c|c|c|c|}
\hline & $\begin{array}{c}\text { Organizational } \\
\text { Culture }\end{array}$ & Performance & $\begin{array}{c}\text { Locus of } \\
\text { Control }\end{array}$ & $\begin{array}{c}\text { Self- } \\
\text { Efficacy }\end{array}$ \\
\hline Discipline & & 0.896638 & & \\
Initiative & 0.794966 & 0.901997 & & \\
Innovation & & 0.935432 & & \\
Quality & & 0.928554 & & \\
Quantity & 0.836665 & & 0.739020 & \\
Logical & 0.857267 & & & \\
Team Orientation & & & 0.779559 & \\
Individual Orientation & 0.883866 & & & \\
Believe Yourself & & & 0.839691 & \\
Attention & & & 0.753123 & \\
Emotional States & & & 0.680049 \\
Loyalty & & & 0.868086 \\
Optimistic & & & 0.870257 \\
Self-Experience & & & \\
Verbal Persuasion & & & \\
Vicarious Experience & & & & \\
\hline
\end{tabular}

Source: Primary data processed, 2019.

The table above shows that the loading factor value provides a value above the recommended value, namely $>0.5$, where the lowest value is 0.680049 for the self-experience indicator. So, it can be interpreted that the hands used in this study are valid or have met the convergent validity.

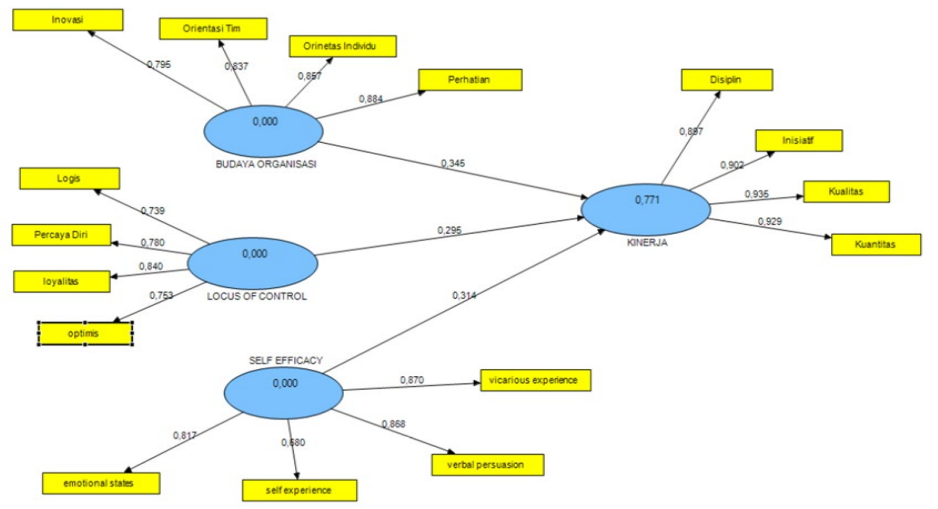

Figure 1. Output Loading Factor 
Proceedings of the 11th Annual International Conference on Industrial Engineering and Operations Management Singapore, March 7-11, 2021

The indicator is declared valid if it has the maximum loading factor for the expected construct relative to other constructs' loading factor value. The test outcome table is above the building value of each main predictor, namely the output efficiency variable, so it may be said that the indicator forecasts the variable better than the hands for other variables.

Table 2. Discriminant Validity Test

Cross Loading Result Table

\begin{tabular}{|c|c|c|c|c|}
\hline & $\begin{array}{c}\text { ORGANIZATI } \\
\text { ONAL } \\
\text { CULTURE }\end{array}$ & Performance & $\begin{array}{c}\text { LOCUS OF } \\
\text { CONTROL }\end{array}$ & $\begin{array}{c}\text { SELF } \\
\text { EFFICACY }\end{array}$ \\
\hline Discipline & 0,687883 & 0,896638 & 0,672544 & 0,758978 \\
\hline Initiative & 0,741185 & 0,901997 & 0,739386 & 0,736884 \\
\hline Innovation & 0,794966 & 0,658538 & 0,705883 & 0,710356 \\
\hline Quality & 0,817201 & 0,935432 & 0,745725 & 0,700848 \\
\hline Quantity & 0,777704 & 0,928554 & 0,762417 & 0,725060 \\
\hline Dwelling & 0,589658 & 0,639941 & 0,739020 & 0,585050 \\
\hline $\begin{array}{c}\text { Team } \\
\text { Orientation }\end{array}$ & 0,836665 & 0,708904 & 0,656114 & 0,648286 \\
\hline $\begin{array}{c}\text { Individual } \\
\text { Orientation }\end{array}$ & 0,857267 & 0,692998 & 0,650585 & 0,574444 \\
\hline Confidence & 0,586569 & 0,559711 & 0,779559 & 0,480051 \\
\hline Attention & 0,883866 & 0,727388 & 0,692935 & 0,708193 \\
\hline $\begin{array}{c}\text { Emotional } \\
\text { States }\end{array}$ & 0,758074 & 0,733820 & 0,639898 & 0,817402 \\
\hline Loyalty & 0,669658 & 0,691308 & 0,839691 & 0,660891 \\
\hline Optimistic & 0,645243 & 0,580181 & 0,753123 & 0,502373 \\
\hline Self Experience & 0,552581 & 0,500862 & 0,445310 & 0,680049 \\
\hline $\begin{array}{c}\text { Verbal } \\
\text { Persuasion }\end{array}$ & 0,630032 & 0,686383 & 0,620391 & 0,868086 \\
\hline $\begin{array}{c}\text { Vicarious } \\
\text { Experience }\end{array}$ & 0,579823 & 0,636296 & 0,614421 & 0,870257 \\
\hline
\end{tabular}

Source : Pls Data Processing Results 2019

The indicator is declared valid if it has the highest loading factor to the intended construct compared to the value of loading factor to other constructs. Tebel test results above the construct value of each of the largest indicators are on quality performance variables, so it can be said that the indicator predicts the variable better than the indicator on other variables.

Another method to view discriminant validity is to look at the variance extracted avarage table (AVE). The recommended value is $>0.5$.

Table 3. Avarage Variance Extracted

\begin{tabular}{|c|c|}
\hline & AVE \\
\hline Organizational Culture & 0,712026 \\
\hline Performance & 0,838701 \\
\hline Locus Of Control & 0,606534 \\
\hline
\end{tabular}


Proceedings of the 11th Annual International Conference on Industrial Engineering and Operations Management Singapore, March 7-11, 2021

\begin{tabular}{|c|c|}
\hline Self Efficacy & 0,660383 \\
\hline Source : Pls Data Processing Results 2019
\end{tabular}

Source : Pls Data Processing Results 2019

The above tebel provides an AVE value of $>0.5$ for all constructs contained in the model. The lowest AVE value is 0.606534 on the locus of control variable.

\section{2) Reliability Test}

SEM reliability is known through the Cronbach's alpha value and composite reliability value $>0.7$. The construct reliability test proves that the constructor indicator constructs (constructs) each variable, the data is reliable if the Cronbach's alpha value is $>0.7$

Table 4. Reliability Test Cronbach's Alpha and Composite Reliability

\begin{tabular}{|c|c|c|}
\hline & Cronbach's Alpha & Composite Reliability \\
\hline Organizational Culture & 0.864586 & 0.908050 \\
\hline Performance & 0.935787 & 0.954111 \\
\hline Locus of Control & 0.783020 & 0.860159 \\
\hline Self-Efficacy & 0.826008 & 0.885156 \\
\hline
\end{tabular}

Source: Primary Data Processed, 2019.

The results above show that the measured variables have Cronbach's alpha and composite reliability values $>0.7$, so it can be said that all variables are declared reliable.

\subsection{Inner Model (Evaluation of Model Structure)}

The inner model is used to measure how much influence the independent latent variable has on the latent dependent variable.

\section{1) R-Squared Test (R2)}

This test is a test to measure the level of goodness of fit of a structural model. This value is used to calculate how much influence the independent latent variable has on the latent dependent variable. R2 results of 0.67 indicate that the model is categorized as useful, $\mathrm{R} 2$ products between 0.330 .67 are categorized as moderate, while R2 products of 0.33 are classified as weak (Ghozali, 2018). The value of 0.770 for the performance variable means that the variable organizational culture, locus of control, and self-efficacy can explain the performance variable by $7.70 \%$.

Table 5. R Square

\begin{tabular}{|c|c|}
\hline & R Square \\
\hline Organizational Culture & \\
\hline Performance & 0,770649 \\
\hline Locus Of Control & \\
\hline Self Efficacy & \\
\hline
\end{tabular}

Source: Primary Data Processed, 2019.

A value of 0.770 for a performance variable can mean that an organization culture variable, locus of control, and self efficacy can describe a performance variable of $7.70 \%$.

\section{5) Hypothesis Test (Signification Test)}

The significance test aims to determine the influence of the independent variable on the dependent variable. The estimated value for the path relationships in the structural model is used to determine the significance of the relationships between latent variables. The significance value can be obtained from the bootstrapping procedure by 
Proceedings of the 11th Annual International Conference on Industrial Engineering and Operations Management Singapore, March 7-11, 2021

looking at the t-count. $>$ t-table is said to be significant. Based on the calculation of the number of samples and the variable t-table value is 1.96 .

Table 6. Path Coefficients (Mean, STDEV, T-Values

\begin{tabular}{|c|c|c|c|c|c|}
\hline & $\begin{array}{c}\text { Original } \\
\text { Sample (O) }\end{array}$ & $\begin{array}{c}\text { Sample } \\
\text { Mean (M) }\end{array}$ & $\begin{array}{c}\text { Standard } \\
\text { Deviation } \\
\text { (STDEV) }\end{array}$ & $\begin{array}{c}\text { Standard } \\
\text { Error } \\
\text { (STERR) }\end{array}$ & $\begin{array}{c}\text { T Statistics ( } \\
\text { O/STERR } \mid)\end{array}$ \\
\hline $\begin{array}{c}\text { Organizational Culture - } \\
\text { Performance }>\end{array}$ & 0,344657 & 0,342617 & 0,087393 & 0,087393 & 3,943761 \\
\hline $\begin{array}{c}\text { Locus Of Control -> } \\
\text { Kinerja }\end{array}$ & 0,294909 & 0,292542 & 0,070167 & 0,070167 & 4,202960 \\
\hline $\begin{array}{c}\text { Self Efficacy - } \\
\text { Performance }>\end{array}$ & 0,314302 & 0,315702 & 0,068060 & 0,068060 & 4,618001 \\
\hline
\end{tabular}

Source: Primary Data Processed, 2019.

Based on the output of table 6 , The predictive value of the organizational culture variable (X1) for the success variable $(\mathrm{Y})$ is $3.94>1.96$. It can be said that this variable has a meaningful impact. The initial survey prediction value indicates a positive value of 0.344 , which is why Hypothesis 1 is acknowledged in this analysis, meaning a positive and significant organizational influence.

\section{Discussion}

Organizational culture is a characteristic of an organization that forms the basis of an organization's rules of behavior. The findings of questionnaire data analysis using smart PLS 2 show that the organizational atmosphere has a significant positive impact on civil servants' success in the PNUP offices. Yusuf's (2016) analysis entitled The Impact of Leadership Style and Organizational Culture on Work Satisfaction and Efficiency of Military Teachers of the VII/Wirabuana Military Regional Command in Sulawesi. In his Hypothesis 4 (four), this study has not been confirmed, and it can be suggested that partially organizational culture hurts performance. However, this analysis is contradicted by this study's findings, which showed that the corporate culture has a positive and essential impact on efficiency, centered on the cross-loading value of 0.727301 between the organizational crocodile variables on the focus measure. The highest amount relative to other metrics on organizational culture variables, i.e., the degree Workers. Thus, if corporate culture's importance rises by $1 \%$, the value of success increases by 0.344 or 3.44 percent. Workers at the PNUP office are very dedicated to the organizational culture of enhancing efficiency, and the corporate culture embraced offers a balanced commitment between organizations and employees. Implementing the organizational culture has the same purpose of empowering and developing the future capital of Ujung Pandang State Polytechnic continuously. The t statistical value for the control variable locus (X2) for the output variable (Y) is $4.20>1.96$, such that it is reported that the variable has a meaningful impact, the initial sample prediction value indicates a positive value of 0.294 . At the same time, Hypothesis 2 in this analysis is acknowledged, indicating a positive and significant influence on the performance of the control variable locus.

Subroto's study (2017) Study of the effect of the Locus of Influence and Work Tension on employee success indicates that whether an employee is willing or unwilling to control incidents that relate to them does not impact his or her results. However, this analysis's findings demonstrate that the management locus has a vital and robust influence on employees' success. It can be seen from the loading factor value of 0.294 and significant $(4.20>1.96)$. Thus, if the control value locus rises by 1 percent, the output value increases by 0.294 or 2.94 percent. On the loyalty metric with the questionnaire argument, that is to add, at my place of employment, those who succeed will earn incentives, and those who perform breaches are subject to penalties, as many as 78 respondents said they firmly agree. Employees of control locus assume that they have a tremendous ability to decide their fate, which implies that they must work well if they wish to be compensated. Employees of control locus have a strong work ethic, are flexible in the face of challenges, control positive conduct, have a high level of job satisfaction, and effectively deal with stress. This is achieved in the PNUP office. Staff who succeed earn rewards, and vice versa, penalties are levied if they commit breaches, as can be seen by the recapitulation of participation and the fulfillment of the goals of the civil servant's results. The t statistical value of the self-efficacy variable (X3) for output (Y) is $4.61>1.96$, so that the variable is said to have a meaningful effect. The initial survey prediction value indicates a positive value of 0.314 , so Hypothesis 3 in this study agrees that there is a positive and vital influence of the self-efficacy variable on results. 
Proceedings of the 11th Annual International Conference on Industrial Engineering and Operations Management Singapore, March 7-11, 2021

Self-efficacy is described as people's confidence in their abilities to practice a variety of measures of self-control. Study Gunawan \& Sutanto (2013) The Impact of Organizational Culture on Employee Success by Self-Efficacy and Disposition at PT. Nutrifood Surabaya insists that self-efficiency does not have a significant influence on employee success at PT. Surabaya Nutrifood. In this research, however, self-efficacy has a positive and considerable effect on civil servants' efficiency in the UNDP of 0.314 and is substantial $(4.61<1.96)$. And they are strongly validated by self-experience or self-experience metrics. Many as 42 respondents reported that they strongly agree with the argument that, if I strive, all problems in carrying out the critical tasks and obligations can be overcome. This proves that workers of self-efficiency focused on their knowledge. A variety of other metrics often strive to overcome the challenges they pose, how much commitment they create, and how immune they meet when conducting their fundamental duties and functions. Employees with a substantial degree of self-efficiency at the PNUP office can improve their competence, but they comply with their essential duties and obligations in some regions.

\section{Conclusion}

The culture that remains in the organization that is embraced should be seen as a reference in workers' actions. However, it can cause the creation of groups that compete with each other. At times, allegiance to groups exceeds the organization's loyalty so that the corporate culture can be generated entirely for the advancement of agencies and not for specific purposes. Control and self-efficacy locus are human taste-related characteristics, meaning that researchers are interested in assessing and evaluating markers for each variable. Identifying control locus and selfefficacy factors can be evaluated when workers start functioning by attitude checks, ensuring that both the organization and the agency are not confused in deciding the job description. This study has restricted support theory. There is a variation in the model, so the researcher proposes multiplying the theory and prior research between factors such that there is little challenge in modifying the model. Each variable in this analysis is a variable that is calculated by many variables. Still, the researcher only takes a few relevant and appropriate indicators for the intent of the test. Smart PLS 2, which researchers use to analyze results, recommends raising the number of samples and measures. If there are indicators that do not fulfill other indicators' criteria, the variables will still be calculated.

\section{References}

Amalini, H., Musadieq, M., \& Afrianty, T. (2016). PENGARUH LOCUS OF CONTROL TERHADAP KEPUASAN KERJA DAN KINERJA (Studi pada Karyawan Perusahaan Daerah Air Minum (PDAM) Kota Malang). Jurnal Administrasi Bisnis S1 Universitas Brawijaya.

Awaluddin, Luthfi, M., \& Yusriadi, Y. (2019). The Effectiveness Of The Implementation Of Independent Community Empowerment Programs In Bone District. International Journal of Scientific \& Technology, 8(8).

A'yun, K., Suyono, Poedjiastoeti, S., \& Bin-Tahir, S. Z. (2017, August). Reduction of cognitive conflict and learning style impact towards student-teacher's misconception load. In AIP Conference Proceedings (Vol. 1868, No. 1, p. 030004). AIP Publishing LLC.

Creswell, J. W. (2016). Research Design (Pendekatan Metode Kualitatif, Kuantitatif, dan Campuran). In Terjemahan Bahasa Indonesia.

Denhardt, R. B., \& Denhardt, J. V. (2000). The new public service: Serving rather than steering. Public Administration Review. https://doi.org/10.1111/0033-3352.00117

Gani, M., Arsyad, M., Syariati, S., Hadi, A., \& Yusriadi, Y. (2019). Success in management of student businesses with personal characteristics, government assistance and entrepreneurship curriculum. International Journal of Recent Technology and Engineering, 8(3).

Ghozali. (2018). Aplikasi Analisis Multivariate dengan IBM SPSS 25. Forum Ilmiah Pendidikan Akuntansi Universitas PGRI Madiun.

Gunawan, K. J., \& Sutanto, E. M. (2013). Pengaruh Budaya Organisasional Terhadap Kinerja Karyawan Melalui Self Efficacy Dan Temperamen Di Pt. Nutrifood Surabaya. Agora.

Julianingtyas, B. N. (2012). Pengaruh Locus Of Control, Gaya Kepemimpinan Dan Komitmen Organisasi Terhadap Kinerja Auditor. Accounting Analysis Journal, 1(1).

Margono, S. (2003). Metodologi Penelitian. In Metodologi Penelitian.

Mustafa, D., Farida, U., \& Yusriadi, Y. (2020). The effectiveness of public services through E-government in Makassar City. International Journal of Scientific and Technology, 9(1).

Oktavia, M. \& S. S. (2017). PENGARUH SELF-EFFICACY DAN LOCUS OF CONTROL TERHADAP KINERJA KARYAWAN DIVISI REDAKSI PT . SEMARANG INTERMEDIA PERS. Jurnal Ilmu Administrasi Bisnis. 
Proceedings of the 11th Annual International Conference on Industrial Engineering and Operations Management Singapore, March 7-11, 2021

Pratiwi, R. (2012). Pengaruh budaya organisasi terhadap kinerja pegawai pada kantor pelayanan kekayaan negara dan lelang Makassar. Jurusan Manajemen Fakultas Ekonomi Dan Bisnis Universitas Hasanuddin.

Rahawarin, M. A., Zacharias, T., Yusriadi, Y., \& Rianti, M. (2020). Dimension of organizational citizenship behavior and its effect toward employees' performance at capital investment and licensing service office South Buru District. Humanities and Social Sciences Reviews, 8(2). https://doi.org/https://doi.org/10.18510/hssr.2020.8276

Rijal, S., Haerani, Y., Mayasari, R. E., \& Yusriadi, Y. (2019). The Effectiveness Of Implementation Of Government Regulation Number 41 The Year 2011 On The Development Of Youth Entrepreneurship And Pioneering And The Provision Of Youth Facilities And Infrastructures In Kolaka. International Journal of Scientific and Technology Research, 8(10).

Rinantanti, Y., Bin-Tahir, S. Z., \& Suriaman, A. (2019). The Impact of EFL Senior High School Teachers' Performance in Papua, Indonesia toward the Students' English Learning Achievement. Asian EFL Journal, 23(3.3), 431-447.

Sahabuddin, C., Muliaty, M., Farida, U., Hasbi, \& Yusriadi, Y. (2019). Administration of post-reformation decentralization government. International Journal of Recent Technology and Engineering, 8(3). https://doi.org/https://doi.org/10.35940/ijrte.c6182.098319

Sahid, A., Amirullah, I., Rahman, A. A., Senaman, A., \& Yusriadi, Y. (2020). The role of the government in supporting the duties of local governments in Makassar City. International Journal of Scientific and Technology Research, 9(3).

Sarwono, J. (2012). Mengenal PLS - SEM. In עלון הנוטע.

Sibuea, A. C. M., \& Rustono, A. (2015). Pengaruh Budaya Organisasi dan Self Efficacy terhadap Kinerja Karyawan pada PT. PLN (persero) Distribusi Jawa Barat dan Banten. E-Proceeding of Management, ISSN : 2355-9357.

Subroto, S. (2017). Analisis Pengaruh Locus Of Control Dan Stres Kerja Terhadap Kinerja Karyawan. Jurnal Ilmiah Manajemen \& Bisnis.

Usman, M. Y., Wibowo, A. D., Laksana, W. U., Yusriadi, Y., \& Sahid, A. (2020). Local government levy optimization. Proceedings of the International Conference on Industrial Engineering and Operations Management.

Wahyuni, E. S., \& Rosmida, R. (2017). ANALISIS PENGARUH BUDAYA ORGANISASI, LOCUS OF CONTROL TERHADAP KINERJA APARAT PEMERINTAH DAERAH DAN KEPUASAN KERJA SEBAGAI VARIABEL INTERVENING (Studi Empiris Pada Pemerintah Kabupaten Bengkalis). Inovbiz: Jurnal Inovasi Bisnis. https://doi.org/10.35314/inovbiz.v5i1.165

Wiriani, W., Piatrini, P. S., Ardana, K., \& Juliarsa, G. (2013). EFEK MODERASI LOCUS OF CONTROL PADA HUBUNGAN PELATIHAN DAN KINERJA PADA BANK PERKREDITAN RAKYAT DI KABUPATEN BADUNG. Jurnal Ilmiah Akuntansi Dan Bisnis.

Yusuf, M. (2016). Pengaruh Gaya Kepemimpinan Dan Budaya Organisasi Terhadap Kepuasan Kerja Dan Kinerja Guru Militer Resimen Induk Komando Daerah Militer Vii/Wirabuana Di Sulawesi. Urnal BISNIS \& KEWIRAUSAHAAN, 5(2).

\section{Biographies}

Fatmawati is a student at Magister Program of Economic Science of STIE AMKOP, Indonesia. Her areas of interest and research include social science and economic.

Hasmin Tamsah is a lecturer at Economics Department of STIE AMKOP, Indonesia. His areas of interest and research include economic, management, management human resource. He has published some books and many articles in national and international journals. He is a reviewer and editor in some local and international journals.

Dian Anggriani Utina is a lecturer at Economics Department of STIE AMKOP, Indonesia. Her areas of interest and research include social science, economic, management, and human resource. She has published articles in national and international journals.

Buyung Romadhoni is a lecturer at Faculty of Economics and Business at Universitas Muhammadiyah Makassar, Makassar, Indonesia. His areas of interest and research include economic, management, management human resource. He has published some books and many articles in national and international journals.

Yusriadi Yusriadi is a lecturer at Public Administration Department of Sekolah Tinggi Ilmu Administrasi Puangrimaggalatung, Indonesia and chancellor on Sekolah Tinggi Ilmu Hukum Pengayoman. His areas of interest 
Proceedings of the 11th Annual International Conference on Industrial Engineering and Operations Management Singapore, March 7-11, 2021

and research include social science, political science, sociology, legal studies, and public administration. He has published some books and many articles in national and international journals. He is a reviewer and editor in some local and international journals.

M Chairul Basrun Umanailo has worked as a Lecturer at Iqra Buru University since 2011 until now he is still active in the University's academic activities. has served as head of the Centre for Planning and Community Development Studies (PSP2M) since 2018. Completed his master's program at Sebelas Maret University in 2016, is currently still completing research on the conversion of agricultural land functions.

Sjaid S Fais Assagaf is one of the technical faculty lecturers of Iqra Buru University who chose to concentrate on the social field of agriculture. Completed undergraduate studies on Indonesian Muslim universities with the development of community infrastructure research. Currently still running research activities on empowering and diversification of agriculture focused on rural areas. 